\title{
A polycystás ovarium szindróma tüneteinek bizonyítékokon alapuló terápiája
}

\author{
Gődény Sándor dr. * Csenteri Orsolya Karola \\ Debreceni Egyetem, Népegészségügyi Kar, Megelőző Orvostani Intézet, Debrecen
}

\begin{abstract}
A polycystás ovarium szindróma a nők leggyakoribb endokrin és anyagcsere-betegsége. A különböző klinikai formában jelentkező betegség kardinális tünetei közé tartoznak a hiperandrogén bőrtünetek és/vagy emelkedett szérumandrogénszintek, oligo- vagy amenorrhoea, anovuláció miatt kialakuló meddőség és esetenként a petefészek polycystás szerkezete. A szindróma kezelése függ a klinikai megjelenéstől, az életkortól, az alkalmazott diagnosztikus technológiák pontosságától, valamint attól, hogy mely kritériumrendszer alkalmazásával történt a diagnózis felállítása. A bizonyítékon alapuló, megfelelóen kiválasztott terápiás technológiával javul a kórkép kezelésének eredményessége, hatékonysága, a betegek biztonsága, életminősége és várható élettartama. A közlemény a rendelkezésre álló irodalmi adatok, elsősorban a legmagasabb szintű bizonyítékoknak tekinthető szisztematikus irodalmi áttekintések és metaanalízisek felhasználásával ismerteti a szindrómához társuló tünetek, az elhízás, a hyperandrogenismus, a vérzészavarok, a meddőség és a lelki problémák kezelésének lehetőségeit. Orv. Hetil., 2015, 156(45), 1803-1815.
\end{abstract}

Kulcsszavak: PCOS, klinikai tünetek, EBM, terápia

\section{Evidence-based therapy of polycystic ovarian syndrome}

Polycystic ovary syndrome is recognized as the most common hormonal and metabolic disorder likely to affect women. The heterogeneous endocrinopathy is characterized by clinical and/or biochemical hyperandrogenism, oligo- or amenorrhoea, anovulatory infertility, and polycystic ovarian morphology. The syndrome is often associated with obesity, hyperinsulinemia and adversely affects endocrine, metabolic, and cardiovascular health. The symptoms and complaint of the patients vary with age. To maximise health gain of the syndrome, adequate, evidence based effective, efficient and safe treatment is necessary. This article summarises the highest available evidence provided by studies, meta-analysis and systematic reviews about the therapeutical possibilities for treating obesity, hyperandrogenism, menstrual abnormalities, infertility and psychological problems related to polycystic ovary syndrome

Keywords: PCOS, clinical features, EBM, therapy

Gödény, S., Csenteri, O. K. [Evidence-based therapy of polycystic ovarian syndrome]. Orv. Hetil., 2015, 156(45), 1803-1815.

(Beérkezett: 2015. július 2.; elfogadva: 2015. szeptember 17.)

\section{Rövidítések}

$2 \mathrm{TDM}=2$-es típusú diabetes mellitus; $\mathrm{A}=$ androsztendion; $\mathrm{BMI}=($ body mass index $)$ testtömegindex $; \mathrm{CC}=$ clomifen-citrát; $\mathrm{CPA}=$ ciproteron-acetát $\mathrm{CI}=($ confidence interval $)$ megbízhatósági tartomány, konfidenciaintervallum; DHEAS = dehidroepiandroszteron-szulfát; DHT = dihidro-tesztoszteron;
DRSP $=$ drospirenon; $\mathrm{EBM}=($ evidence-based medicine $)$ bizonyítékokon alapuló orvoslás; $\mathrm{EE}=$ etinil-ösztradiol; $\mathrm{EE}+\mathrm{CPA}=$ etinil-ösztradiolt és ciproteron-acetátot tartalmazó kombinált készítmény; EE+DRSP = etinil-ösztradiolt és drospirenont tartalmazó kombinált készítmény; EMA = (European Medicines Agency) Európai Gyógyszerügynökség; FAI = (free androgen 
index $)$ szabadandrogén-index; FDA = (Food and Drug Administration) Amerikai Egyesült Államok Élelmiszer- és Gyógyszerbiztonsági Hatósága; FG-score = Ferriman-Gallwey-hirsutismus-score; FSH = folliculusstimuláló hormon; $\mathrm{fT}=($ free testosterone) szabad tesztoszteron; $\mathrm{GnRH}=$ gonadotropin-releasing hormone; hCG = humán choriogonadotropin; HDL-C = HDL-koleszterin; HOMA = homeostasis model assessment; hsCRP = high-sensitivity C-reactive protein; IFG = (impaired fasting glucose) emelkedett éhomi vércukor; IGT $=$ (impaired glucose tolerance) csökkent glükóztolerancia; IR = inzulinrezisztencia; IVF = in vitro fertilizáció; LDL-C = LDL-koleszterin; $\mathrm{LH}=$ luteinizáló hormon; LOD = laparoscopic ovarian „drilling"; $\mathrm{MD}=$ (mean difference $)$ átlagok különbsége; MET $=$ metformin; NIH = National Institutes of Health; NNT = (number needed to treat) minimálisan szükséges betegszám, hogy egy betegnél a kívánt hatást elérjük; $\mathrm{OCP}=($ oral contraceptive pill) hormonális fogamzásgátló tabletta; OHSS = (ovarian hyperstimulation syndrome) ovarialis hiperstimulációs szindróma; $\mathrm{OR}=($ odds ratio) $)$ esélyhányados; $\mathrm{p}=\mathrm{p}$-érték $(\mathrm{az}$ első fajta hiba - a nullhipotézis hibás elvetése - valószínúségét adja meg); $\mathrm{PCO}=$ polycystás ovarium, polycystás petefészek; $\mathrm{PCOS}=$ polycystás ovarium szindróma $\mathrm{RR}=$ (relative risk $)$ relatív kockázat; $\mathrm{RTC}=($ randomized controlled trial $)$ randomizált kontrollált tanulmány; SHBG $=($ sex hormone binding globulin) szexhormonkötő globulin; SR = (systematic review) szisztematikus irodalmi áttekintés; TT = össztesztoszteron; VTE = vénás thromboembolia; WHR (waist-hip ratio) derékcsípó arány; WMD = (weighted mean difference) súlyozott átlag különbsége

A polycystás ovarium szindróma (PCOS) prevalenciája, a vizsgált populációtól és az alkalmazott diagnosztikus kritériumok alkalmazásától függően, 5-10\% közötti, ezért a fertilis korban levő nők leggyakoribb endokrin kórképének tekinthető [1].

Az Egészségügyi Világszervezet (WHO) által II. osztályba sorolt normogonadotrop anovulációban szenvedőket vizsgálva, a szindróma gyakorisága $55 \%$ volt a National Institutes of Health (NIH) 1990-es kritériuma szerint. Ezzel szemben, ha ugyanezen betegeknél a 2003-as Rotterdami kritériumokat alkalmazták, a PCOS aránya eléri a 91\%-ot [2]. A klinikai gyakorlatban a vérzészavarban szenvedők között tehát igen gyakori a kórkép előfordulása, ugyanakkor a betegek bizonyítékokon alapuló, komplex terápiája és gondozása még napjainkban sem megoldott.

A szindróma központi tünete az ovarialis eredetú hyperandrogenismus, amelyhez gyakran inzulinrezisztencia (IR) is társul. A PCOS-ben kialakuló IR prevalenciája elérheti az 50-80\%-ot, ha a NIH-kritériumok alkalmazása alapján történik a kórkép diagnózisa és a betegek testtömegindexe $(\mathrm{BMI})>25$ [3]. A hyperandrogenismus és az IR lényeges szerepet játszanak mind a PCOS tüneteinek, mind szövődményeinek kialakulásában.

A PCOS etiológiájában genetikai és életmódbeli tényezőknek is jelentőségük van, de ezeket a géneket az eddigi kutatások pontosan még nem térképezték fel [4].
Korábbi közleményünkben [Gödény S., Csenteri O.: A polycystás ovarium szindróma interdiszciplináris, bizonyítékokon alapuló diagnózisának fontossága. Orv. Hetil., 2014, 155(30), 1175-1188.)] már ismertettük a PCOS-ben kialakuló szövődményeket, a diagnosztikus kritériumok új szempontjait, a jelenleg alkalmazható diagnosztikus technológiák előnyeit-korlátait, továbbá a kórkép bizonyítékokon alapuló alapelveit figyelembe vevő, interdiszciplináris diagnózisának fontosságát.

Jelen cikkben a komplex tünetekkel járó kórkép bizonyítékokon alapuló terápiájának alapelvei és az alkalmazható terápiás technológiák kerülnek ismertetésre.

\section{A strukturált irodalomkutatás módszere}

Az irodalmi összefoglalóban felhasználtuk a PubMed, a Cochrane Library (CDSR, DARE, HTA), a BioMed Central, a Clinical Key, a POPLINE, a Magyar Orvosi Bibliográfia adatbázisokat, a Clinical Evidence értékeléseit.

Az irodalomkeresésnél használt kifejezések: PCOS, hyperandrogenism, hirsutism, acne, obesity, hyperinsulinaemia, IFG, IGT, weight management, cardiometabolic, cardiovascular risk, infertility, pregnancy, systematic review, meta-analysis evidence based, interdisciplinary, therapy, antiandrogens, hormonal contraception, ovulatio induction, insulin sensitisers, metformin.

Az összeállításban továbbá felhasználásra kerültek a bizonyítékokon alapuló orvoslás (EBM) és a terápiás technológiák alkalmazásának alapelveivel kapcsolatos publikációk.

\section{A kezelés általános alapelvei}

A PCOS kezelésének alapelveit az alkalmazott technológia, a szindróma elsődleges klinikai képe, a beteg panaszai és a nők életszakasza határozza meg.

A terápiás kezeléseknek két fó céljuk van:

- kezelni a beteg aktuális problémáját, panaszát,

- megelőzni a későbbi anyagcsere-, cardiovascularis és onkológiai problémákat.

Gyermekkorban az elhízás, serdülőkorban a hiperandrogén tünetek és a menstruáció rendellenességei a vezető tünet, fertilis korban ez kiegészül a meddőségi panaszokkal. Peri- és posztmenopauzában az anyagcserezavarok és a társuló szövődmények jelentik a legnagyobb problémát.

Az elhízás, fenotípustól függően, a gyermekkor utáni időszakban is részét képezheti a tüneteknek. A lelki problémák ugyancsak több életszakaszon keresztül jelenthetnek gondot a betegeknek.

A PCOS korszerű kezeléséhez és időben történő gondozásához lényeges, hogy a kórkép minél hamarabb, lehetőleg már gyermek- vagy serdülőkorban kerüljön felismerésre.

A serdülőkor gyorsan változó hormonális és szomatikus változásai miatt ebben az életszakaszban a PCOS te- 
rápiája különösen nagy kihívást jelent. Fontos a rendszeres gondozás, ugyanis ez kihatással van a későbbi életszakaszokra is [5].

A terápia lépéseit az is befolyásolja, hogy melyik diagnosztikus kritérium alapján történt a diagnózis. A NIHkritériumrendszer szerinti betegeknél inkább a hyperandrogenaemia és annak tünetei, az anyagcserezavarok fokozott kockázata határozza meg a szükséges terápiás beavatkozás és gondozás alapvető szempontjait, míg a 2003-as Rotterdami kritériumrendszer szerinti diagnózis inkább a menstruációs és infertilitási zavarok kezelését helyezi előtérbe $[6,7]$. A PCOS kezelésének életszakaszonkénti fóbb szempontjait az 1. ábra ismerteti [8].

A prevenciós és terápiás terv felállításánál alapelvnek tekinthető, hogy a hiperandrogén bőrtüneteket, a menstruációs ciklust, a fertilitás megőrzését, az elhízást, a lelki panaszokat és az anyagcsere-elváltozásokat, továbbá a későbbi szövődmények kialakulásának esélyét együttesen szükséges figyelembe venni. A kezelés elvi lehetőségeit az 1. táblázat foglalja össze.

\section{A PCOS kezelése a tünetek és az alkalmazott terápiák szerint}

A PCOS-nél alkalmazott eljárások legtöbbjénél - a nem egységes diagnosztikus kritériumok, vizsgálati eljárások és szempontok miatt - még nem rendelkezünk magas validitású, egyértelmű bizonyítékokkal. Ezért a prevenciós és terápiás eljárások eredményességeinek értékelései nem zárultak le, az azokat vizsgáló kutatások jelenleg is folyamatban vannak.

\section{Az elhizás kezelése}

PCOS-ben nő a túlsúlyos állapot és az elhízás ezen belül az abdominalis típus kialakulásának esélye. Az elhízás következményei hívják fel a figyelmet arra, hogy - a panaszoktól és az egyéb tünetekre alkalmazott terápiától függetlenül - a társuló túlsúly vagy elhízás csökkentése a PCOS-betegek gondozásának szerves részét kell, hogy képezze [9].

Különösen fontos a testtömeg csökkentése gyermekés serdülőkorban, mert így eredményesen javul a kóros glükózanyagcsere, a késôi szövődmények kialakulásának esélye csökken és az életminőség is javul [10, 11, 12].

Az elhízás kezelése komplex feladat, de elsősorban az életmód megváltoztatásától, a diétától (magas glykaemiás indexű szénhidrátok, telített zsírsavakat tartalmazó étrend és a konyhasóbevitel csökkentése, fehérje- és rostdús ételek fogyasztása) és a fokozott mozgástól várhatunk eredményt [13].

A rendszeres testmozgás nélkülözhetetlen, de a mozgás legkedvezőbb formája még nem minden szempontból ismert [14]. Ugyanakkor azt fontos hangsúlyozni, hogy csak a kombinált programmal (diéta+fokozott

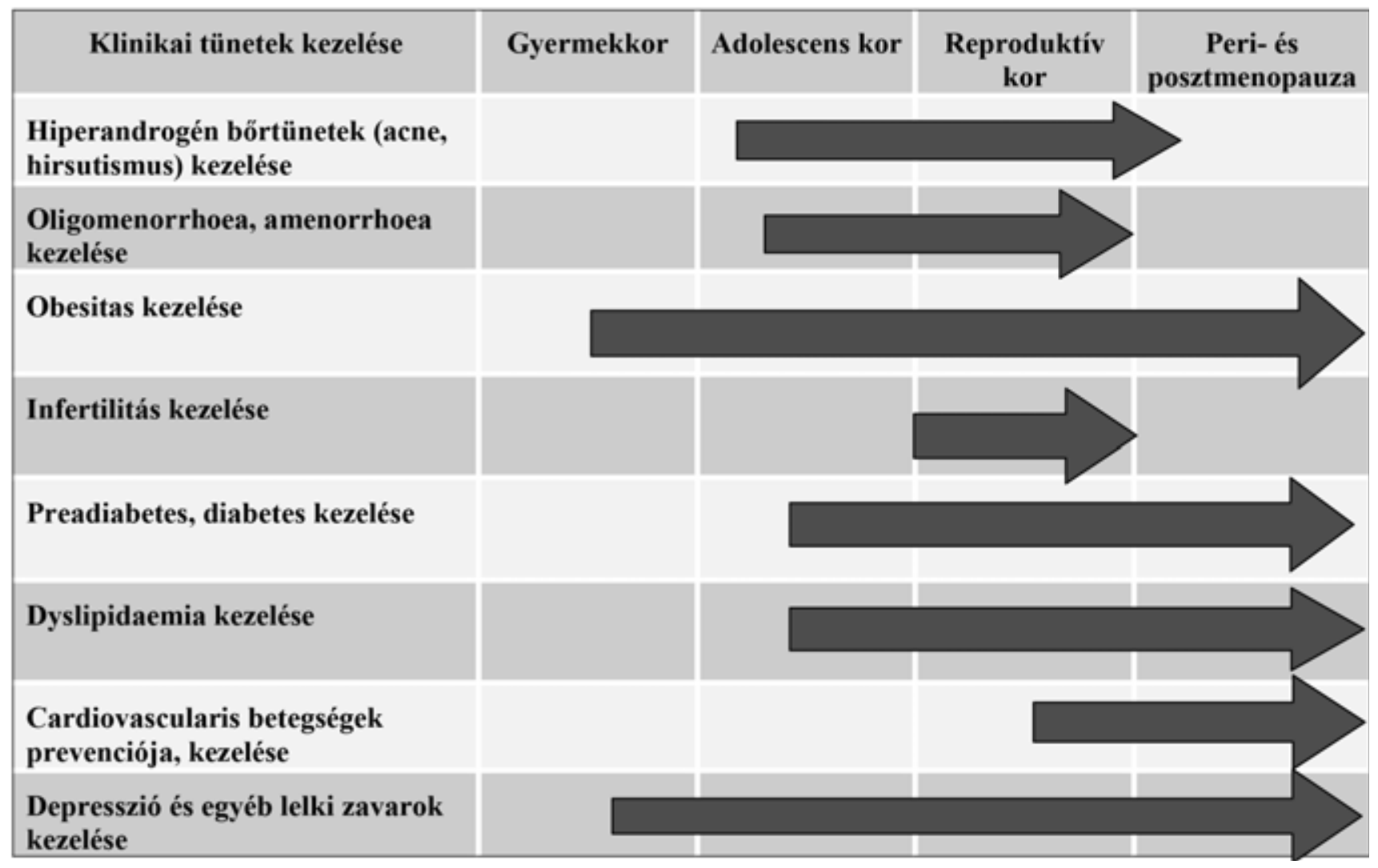

1. ábra | A PCOS kezelésének főbb szempontjai életszakaszonként (forrás: NIH) [8] 
1. táblázat | A PCOS kezelésének elvi lehetőségei

\begin{tabular}{|c|c|}
\hline Kezelés célja & Elvi lehetőségek \\
\hline 1. Az androgén hatás csökkentése & $\begin{array}{l}\text { - Gyógyszeres: } \\
\text { - a petefészek androgéntermelésének visszaszorítása (OCP, EE+CPA) } \\
\text { - a mellékvese fokozott androgéntermelésével is járó kombinált formák esetén (hidrokortizon, } \\
\text { kortizon-acetát, prednizolon, dexamethason) }\end{array}$ \\
\hline 2. Az androgenizációs tünetek csökkentése & $\begin{array}{l}\text { - Antiandrogének (ciproteron-acetát, flutamid, finasterid, spironolacton) } \\
\text { - Acne lokális vagy szisztémás kozmetológiai kezelése: } \\
\text { - szisztémás (izotretinoin, clindamycin) } \\
\text { - lokális (benzoil-peroxid, adapalen, erythromycin, clindamycin, sodium sulfacetamid) } \\
\text { - Hirsutismus lokális kozmetológiai kezelése (eflornithin, epiláció, depiláció) } \\
\text { - Hyperinsulinismus csökkentése (metformin?) }\end{array}$ \\
\hline 3. Vérzészavarok kezelése & $\begin{array}{l}\text { - OCP } \\
\text { - Ovulációindukció } \\
\text { - Hyperinsulinismus csökkentése }\end{array}$ \\
\hline 4. Meddőségi panaszok kezelése & $\begin{array}{l}\text { 4/a) Az FSH-deficientia pótlása: } \\
\text { - clomifen-citrát (Clostilbegyt) } \\
\text { - gonadotropinok alkalmazása } \\
\text { - hyperinsulinismus csökkentése (metformin?) } \\
\text { 4/b) Mütéti eljárások (endokoaguláció, lézervaporizáció [ODL]) } \\
\text { 4/c) IVF-ET. }\end{array}$ \\
\hline 5. Elhízás kezelése & $\begin{array}{l}\text { - Életmód változtatása (diéta, fokozott testmozgás) } \\
\text { - Gyógyszeres kezelés (orlistat) } \\
\text { - Hyperinsulinismus csökkentése (metformin?) } \\
\text { - Mútét (szúkületet képező eljárások, tápanyag-felszívódást megakadályozó eljárások) }\end{array}$ \\
\hline $\begin{array}{l}\text { 6. Cardiovascularis prevenció, } \\
\text { anyagcserezavarok kezelése }\end{array}$ & $\begin{array}{l}\text { - Életmód változtatása (diéta, fokozott testmozgás) } \\
\text { - Igazolt IGT, IFG esetén metformin a hyperinsulinaemia gyógyszeres kezelésére } \\
\text { - Diabetes gyógyszeres kezelése } \\
\text { - Dyslipidaemia gyógyszeres kezelése } \\
\text { - Hypertonia kezelése }\end{array}$ \\
\hline 7. Pszichés zavarok kezelése & $\begin{array}{l}\text { - Pszichológiai eljárások } \\
\text { - Pszichiátriai eljárások }\end{array}$ \\
\hline 8. Onkológiai prevenció & $\begin{array}{l}\text { - Endometriumcarcinoma szúrése és ellátása } \\
\text { - Emlö- és petefészekrák szû́rése és ellátása }\end{array}$ \\
\hline
\end{tabular}

mozgás) érhető el hosszabb távon kedvező eredmény [15].

A gyógyszeres terápia lehetősége korlátozott. A sebészeti megoldás csak 40 feletti BMI esetén és a diéta betartása szempontjából együttmúködő betegeknél jön szóba [16].

\section{Az életmód-változtatások hatásai}

Az életmód-változtatásnak több paraméterre is kedvező hatása van rövid távon, bár ezek pontosabb megítélésére további vizsgálatok szükségesek.

A 2011-ben megjelent Cochrane review szerint az életmód-változtatás (diéta, fokozott mozgás) kedvező a testtömeg és a haskörfogat csökkentésére (testtömeg: MD -3,47 kg [95\% CI: $(-4,94)-(-2,00)], \mathrm{p}<0,00001$; haskörfogat: $\mathrm{MD}-1,95 \mathrm{~cm}[95 \% \mathrm{CI}:(-3,34)-(-0,57)]$, $\mathrm{p}=0,006)$. Kedvező a hirsutismusra Ferriman-Gallweyhirsutismus-score (FG-score) szerint (MD -1,19 [95\% CI: $(-2,35)-(-0,03)], p=0,04)$ és az éhomi inzulin csökkenésére $(\mathrm{MD}-2,02 \mathrm{\mu U} / \mathrm{mL}, \quad[95 \% \mathrm{CI}$ : $(-3,28)-(-0,77)], \mathrm{p}=0,002)$, a össztesztoszteronra (TT) (MD: $-0,27 \mathrm{nmol} / \mathrm{L}[95 \% \mathrm{CI}:(-0,46)-(-0,09)]$, $\mathrm{p}=0,004)$. Nem igazoltak szignifikáns hatást a free an- drogen index (FAI), a szexhormonkötő globulin (SHBG), a glükóz- és a koleszterinértékekre [17].

$\mathrm{Az}$ életmód-változtatás kedvező szomatikus hatását későbbi vizsgálatok is megerősítették. Ezek a kutatások az éhomi vércukor, az inzulin, a lipidprofil, a folliculusstimuláló hormon (FSH), az SHBG, a TT, az androsztendion (A) és a FAI értékeinek javulását is leírták [18, 19].

\section{Az elhízás gyógyszeres kezelése}

Amennyiben a diétával és a fokozott mozgással a testtömegcsökkenés nem megfelelő mértékű, kiegészítő gyógyszeres terápia is szükséges. Magyarországon jelenleg még csak az orlistattartalmú készítmények vannak forgalomban. Három hónapig történő alkalmazásával átlagosan 7,81 $\pm 0,66 \mathrm{~kg}$ csökkenés érhető el, míg a csak életmódváltozást folytató kontrollcsoportban ez az érték $4,7 \pm 0,26 \mathrm{~kg}$. Az orlistatot metforminnal (MET) összehasonlítva, a BMI változásában különbséget nem igazoltak, de a derék-csípó arány (WHR) csökkenése szignifikánsan nagyobb mértékű volt az orlistatcsoportban $(3,0 \pm 0,3 \mathrm{~cm}$ versus $2,1 \pm 0,2 \mathrm{~cm})$. A csak életmód-változ- 
tatást folytató csoporthoz viszonyítva az orlistat kedvezően hatott a lipidprofilra is [20].

A lorcaserint (5-HT2c receptorok szelektív agonista) és a phentermin/topiramat hatóanyagokat tartalmazó kombinált készítményt (szimpatomimetikum és egy antiepileptikum alacsony dózisú kombinációja) 2012-ben fogadta el az Amerikai Egyesült Államok Élelmiszer- és Gyógyszerbiztonsági Hatósága (FDA) az elhízás kezelésére. Mindkét készítmény szignifikánsan csökkenti a testtömeget (lorcaserin 3\%-kal [95\% CI: 3,0-4,0], phentermin és topiramat 7\%-kal [95\% CI: 3-4]) [21]. A készítmények mellékhatásai miatt az Európai Gyógyszerügynökség (EMA) 2013-ban elutasította az európai forgalmazást.

2014 szeptemberében az FDA egy újabb kombinációt, a naltrexon-hidroklorid és bupropion-hidroklorid tartalmú (hypothalamus szintjén ható készítmény) gyógyszer alkalmazását fogadta el. A készítmény alkalmazásának feltétele a 30-nál nagyobb BMI. A készítmény alkalmazható akkor is, ha a BMI 27-nél kisebb és még legalább egy, a testtömeg-növekedéssel kapcsolatos szövődmény (hypertonia, hypercholesterinaemia vagy 2-es típusú diabetes mellitus) igazolható. A nyújtott hatóanyag-felszabadulású kombinált készítménnyel átlagosan 4,6\%-os testtömegcsökkenés (95\% CI: 4,4-4,8) érhető el [22]. A gyógyszer európai forgalmazását Mysimba néven az EMA is támogatta, és 2015. március 26án az Európai Bizottság kiadta az Európai Unió egész területére érvényes forgalomba hozatali engedélyt. Elhízott PCOS-betegekre vonatkozó adatok azonban még nem állnak rendelkezésre.

$\mathrm{Az}$ eredetileg 2TDM kezelésére kifejlesztett liraglutidot (humán glükagonszerú peptid-1 [GLP-1] receptoragonista) az FDA 2014 decemberében fogadta el az elhízás kezelésére. PCOS-ben történő alkalmazása fóleg a nagyobb metabolikus kockázattal járó fenotípusnál lehet előnyös [23].

2015. június 30-ig Magyarországon még egyik készítmény sem volt forgalomban az elhízás kezelésére.

\section{A metformin alkalmazása}

A metformin eredményessége kérdéses az elhízás kezelésére [24]. Placebóval és életmód-változtatással összehasonlítva legalább 8 hetes kezelés során a BMI szerény

2. táblázat |Az elhízás kezelésére alkalmazható készítmények összehasonlító eredményessége PCOS-ben

\begin{tabular}{|c|c|c|c|c|c|}
\hline Alkalmazott kezelés & $\begin{array}{l}\text { Viszonyított kezelés } \\
\text { (kontroll) }\end{array}$ & $\begin{array}{l}\text { Kezelés eredményessége } \\
\text { a kontrollhoz viszonyítva }\end{array}$ & Megjegyzés, értékelés & $\mathrm{E}$ & $\mathrm{R}$ \\
\hline $\begin{array}{l}\text { Orlistat }(2 \times 120 \mathrm{mg}) \\
\text { +életmód- } \\
\text { változtatás }\end{array}$ & Életmód-változtatás & $\begin{array}{l}\text { BMI-változás }(\%): \\
-8,12 \pm 6,71 \text { vs. } 4,6 \pm 0,27 \\
\text { WHR-változás }(\%): \\
-3,0 \pm 0,3 \text { vs. } 1,2 \pm 0,3\end{array}$ & $\begin{array}{l}\text { A Rotterdam kritériumok szerint diagnosztizált } \\
\text { PCOS-betegnél az életmódváltozás mellett } \\
\text { kiegészítő terápiaként alkalmazott orlistat } \\
\text { eredményes. }\end{array}$ & $1 b$ & 21 \\
\hline $\begin{array}{l}\text { Orlistat+életmód- } \\
\text { változtatás } \\
(2 \times 120 \mathrm{mg})\end{array}$ & $\begin{array}{l}\text { MET* }^{*} \\
\text { (1500 mg/nap) } \\
\text { +életmód-változtatás }\end{array}$ & $\begin{array}{l}\text { BMI-változás }(\%): \\
-8,12 \pm 6,71 \text { vs. } 8,4 \pm 0,65 \\
\text { WHR-változás }(\%): \\
-3,0 \pm 0,3 \text { vs. } 2,1 \pm 0,2\end{array}$ & $\begin{array}{l}\text { A metformin nem eredményesebb az orlistatnál a } \\
\text { BMI csökkenése szempontjából. } \\
\text { A haskörfogatot az orlistat jobban csökkentette } \\
(\mathrm{p}=0,012) \text {. }\end{array}$ & $1 b$ & 21 \\
\hline $\begin{array}{l}16 \mathrm{mg} \\
\text { naltrexon+90 mg } \\
\text { bupropion/nap } \\
\text { +életmód- } \\
\text { változtatás }\end{array}$ & $\begin{array}{l}\text { Placebo+életmód- } \\
\text { változtatás }\end{array}$ & $\begin{array}{l}\text { Testtömegváltozás }(\mathrm{kg}) \\
4,6 \% \text {-os testtömegcsökkenés } \\
(95 \% \mathrm{CI}: 4,4-4,8)\end{array}$ & $\begin{array}{l}\text { FDA új törzskönyvezés. } \\
\text { Elhízott PCOS-betegekre vonatkozó adatok még } \\
\text { nem állnak rendelkezésre. }\end{array}$ & & 23 \\
\hline $\begin{array}{l}\text { Liraglutid } \\
\text { (napi: } 1,2 \mathrm{mg} \text { ) }\end{array}$ & $\begin{array}{l}\text { MET* }^{*} \\
(1000 \mathrm{mg} / \mathrm{nap})\end{array}$ & $\begin{array}{l}\text { BMI-csökkenés: } \\
\text { Liraglutid: }-2,13 \mathrm{~kg} / \mathrm{m}^{2} \\
\text { MET: } 0,62 \mathrm{~kg} / \mathrm{m}^{2} \\
\text { Metabolikus szindróma aránya } \\
\text { kezelés után: } \\
\text { Liraglutid: } 29 \% \\
\text { MET: } 47 \%\end{array}$ & $\begin{array}{l}\text { Jelenleg még nincs elegendő adat a liraglutid } \\
\text { kedvezô hatásának egyértelmú megítélésére } \\
\text { PCOS-betegeknél alkalmazva. }\end{array}$ & $2 b$ & 24 \\
\hline $\begin{array}{l}\mathrm{MET}^{*} \text { (napi } \\
1500-2550 \mathrm{mg})\end{array}$ & Életmód-változtatás & $\begin{array}{l}\text { BMI-változás } \\
\text { WMD: } \\
-0,68[95 \% \mathrm{CI}:(-1,13)- \\
(-0,24)]\end{array}$ & $\begin{array}{l}\text { Legalább } 8 \text { hetes kezelést követóen. Nagyobb } \\
\text { dózis }(1500 \mathrm{mg}) \text { és } 12 \text { hétnél hosszabb ideig tartó } \\
\text { kezelés várhatóan kedvezőbb. }\end{array}$ & $2 b$ & 26 \\
\hline
\end{tabular}

A 2-5. táblázatokban alkalmazott rövidítések:

* = off label alkalmazás; E = level of evidence (a felhasznált irodalomra vonatkozó bizonyítékszint, Centre for Evidence-based Medicine, Oxford ajánlása szerint); R (referencia) = hivatkozott irodalom.

$\mathrm{BMI}=($ body mass index $)$ testtömegindex $\mathrm{CC}=$ clomifen-citrát $; \mathrm{CI}=$ konfidenciaintervallum; $\mathrm{CPA}=$ ciproteron-acetát $; \mathrm{EE}+\mathrm{CPA}=\mathrm{etinil-ösztra-}$ diolt és ciproteron-acetátot tartalmazó kombinált készítmény; EE+DRSP = etinil-ösztradiolt és drospirenont tartalmazó kombinált készítmény; FG-score = Ferriman-Gallwey-hirsutismus-score; GnRH = gonadotropin-releasing hormone; IVF = in vitro fertilizáció; NORG = norgesztimát; OCP = hormonális fogamzásgátló tabletta; OHSS = ovarialis hiperstimulációs szindróma; OR = esélyhányados; WHR = derék-csípő arány; WMD = súlyozott átlag különbsége. 
mértékben, de szignifikánsan csökkent (WMD: $-0,68$ [95\% CI: $(-1,13)-(-0,24)])[25]$. A kezelési idő meghosszabbítása nem növelte az eredményességet, 12 hónapos MET-kezelés alatt a testtömegcsökkenés mediánja $3 \mathrm{~kg}$ volt $(25-75$ percentilis: $-10,3-0,6)[26]$.

A klinikailag nem jelentôs testtömegcsökkenést igazoló kutatási eredmények ellenére az Endocrine Society aktuális irányelve a MET alkalmazását túlsúlyos vagy elhízott adolescens korú PCOS-betegeknél javasolja, különösen akkor, ha emelkedett éhomi vércukor (IFG) és/ vagy csökkent glükóztolerancia (IGT) igazolható, továbbá az életmód-változtatás korábban eredménytelen volt [27].

Túlsúlyos vagy elhízott gyerekeknél, serdülőknél a hosszabb távú MET-terápia biztonságának és eredményességének értékelései még folyamatban vannak [28] (2. táblázat).

\section{A menstruációs zavarok kezelése}

\section{A hormonális fogamzásgátlók alkalmazása}

A vérzészavar kezelésére, amennyiben a betegnek meddőségi panasza nincs, fŏleg az alacsony androgenitású gesztagéneket (például dezogesztrelt, gesztodént, norgesztimátot vagy drospirenont dienogesztet vagy klormadiont) tartalmazó fogamzásgátlók alkalmazását a legtöbb irányelv jelenleg is az első vonalbeli kezelésként ajánlja. A fogamzásgátló hatású készítmények előnye, hogy az FSH és a luteinizáló hormon (LH) kiáramlásának gátlásával csökkentik a petefészek-eredetú androgénszintézist, emelik az SHBG-t, ennek következtében csökken a szabad androgén (fT) aránya, amely csökkentheti a hiperandrogén tüneteket. A hormonális fogamzásgátló tabletta $(\mathrm{OCP})$ alkalmazása megelózheti az endometriumcarcinoma kialakulását is [29].

A megfelelő készítmény kiválasztásánál ugyanakkor figyelembe kell venni, hogy főleg a gesztagén komponens fokozhatja a vénás thromboembolia (VTE) kockázatát. A VTE kockázata készítményenként eltérő; alacsonyabb kockázattal bírnak a levonorgesztrelt tartalmazó, farmakológiai szempontból magasabb androgenitású készítményekhez viszonyítva. A noretiszteront vagy a norgesztimátot tartalmazó készítmények esetén a levonorgesztrelhez viszonyított relatív kockázat (RR) nem növekszik, míg a gesztodént, dezogesztrelt, drospirenont (DRSP) tartalmazó készítményeknél az RR: 1,52,0 , az etonogesztrelt, norelgesztromint tartalmazó készítményeknél RR: 1,0-2,0 [30].

Az OCP tartós alkalmazásánál felmerül, hogy milyen mértékben befolyásolják a PCOS-betegek laboratóriumi eredményeit és a végső, kemény végpontokat. A kérdésre - tekintettel arra, hogy PCOS-betegeknél ilyen irányú randomizált kontrollált tanulmányok (RTC-k) nem történtek - jelenleg még egyértelmú választ nem lehet adni. A Cochrane Menstrual Disorders and Subfertility Group által 2006-ban végzett szisztematikus irodalmi áttekintés szerint, az akkori kutatási eredmények alapján, nem volt egyértelmúen igazolható, hogy a hormonális fogamzásgátlók kedvezôtlenül befolyásolnák a PCOS-betegek éhomi vércukor- és összkoleszterinszintjét a metforminnal kezeltekhez viszonyítva. Nincs hatásuk az inzulinszintre sem, de a metforminhoz viszonyítva jobban csökkentik a TT-koncentrációt [31]. Egy később publikált szisztematikus irodalmi áttekintés (SR) szerint, amely legalább három hónapig tartó, 35 prospektív kohorsz- és RTC-tanulmányt értékelt, az OCP-k szignifikánsan emelik az összkoleszterin-, LDL-koleszterin- (LDL-C-), HDL-koleszterin- (HDL-C-), triglicerid- és éhomi vércukorszintet. A glükóz/inzulin arány és a homeostasis model assessment inzulinrezisztencia (HOMA-IR) nem változott az OCP alkalmazása alatt. A kutatási adatok értékelésénél figyelembe kell venni, hogy a vizsgálatok szignifikáns heterogenitást mutattak a kezelés előtt az éhomi vércukor, a HOMA-index, a koleszterin, a HDLC, LDL-C, a triglicerid, a BMI és az életkor vonatkozásában, továbbá az életmódbeli különbségek is befolyásolhatják a vizsgálat eredményét [32].

Prospektív kohorszvizsgálat szerint normális testtömegú PCOS-betegeknél 6 hónapig alkalmazott etinilösztradiolt és drospirenont (EE-DRSP) tartalmazó $\mathrm{OCP}+$ spironolacton kombináció nem befolyásolta a BMI-t, a derék-csípó arányt, az LDL-, HDL-koleszterol- és a trigliceridszinteket, valamint a glükóztoleranciát. A hirsutismus (FG-score szerint), a TT és a FAI csökkent, a high-sensitivity C-reactive protein hsCRP- és a homociszteinkoncentráció a 6 . hónap végére megemelkedett. Az utóbbi két biomarker koncentrációja a fokozott cardiovascularis kockázatra utalhat [33].

Összegezve az eddigi kutatások adatait, az OCP alkalmazásának előnyei lényegesen meghaladják a várható kockázatokat [34].

Tekintettel arra, hogy az OCP-k cardiovascularis kockázata egyértelmúen nem zárható ki, fólleg a NIH-kritériumok szerinti diagnózis esetén, akiknél túlsúly, elhízás, IR, hyperandrogenaemia vagy dyslipidaemia igazolható, és a fogamzásgátlás igénye is felmerül, a menstruáció rendezésére elsősorban az etonogesztrelt és etinil-ösztradiolt tartalmazó hüvelygyúrü alkalmazása javasolt [35].

Akiknél az ösztrogén alkalmazása kockázatos, alternatív kezelésként ciklusos progeszteronszubsztitúció is szóba jön [36].

Levonorgestrelt tartalmazó méhen belüli eszközök (IUD-k) biztonságáról megbízható adatok még nem állnak rendelkezésre PCOS-betegekre vonatkozóan.

\section{A metformin alkalmazása}

Az eddig publikált vizsgálatok SR-je szerint, bár a metformin nagyobb mértékben csökkenti az inzulinszintet PCOS-betegeknél, kevésbé eredményes a rendszertelen menzesz kezelésére, mint az OCP-k (OR): 0,08 (95\% CI: 0,01-0,45) [31]. 


\section{A hiperandrogén börtünetek kezelése}

A PCOS-ben acne, hirsutismus és ritkábban androgén alopecia alakul ki. Az enyhe fokú hiperandrogén bőrtünetek (papulopustular acne, acne conglobata) tüneti kezelésére, a lokális vagy szisztémás bőrgyógyászati kezelésen kívül, OCP-k vagy fogamzásgátló hatású ciproteron-acetátot tartalmazó készítmények alkalmazhatók.

Fontos hangsúlyozni, hogy amennyiben az FG-score 8 pont alatti, a hirsutismus kizárható, tehát kezelés nem indokolt [37]. A gyakorlat számára lényeges szempont, hogy a hiperandrogén bőrtünetek terápiájánál a szérumandrogénszinteket nem feltétlenül szükséges figyelembe venni, ugyanis azok nincsenek szoros kapcsolatban a hiperandrogén bőrtünetek súlyosságával.

\section{A hormonális fogamzásgátlók alkalmazása}

Az OCP-k antiandrogén hatását lényegesen meghatározza azok gesztagéntartalma. A legerősebb antiandrogén hatású a ciproteron-acetát. Hershberger-teszt szerint a dienogeszt és a drospirenon antiandrogén hatása a ciproteron-acetát 40, illetve 30\%-a [38]. Lényeges tudni, hogy a ciproteron-acetátot tartalmazó készítmények Magyarországon csak antiandrogén terápiaként vannak törzskönyvezve, nem fogamzásgátlóként.

Az eddigi klinikai vizsgálatok szerint az acne kezelésére a klór-madinont tartalmazó készítmények eredményesebbek a levonorgesztreltartalmú készítményeknél, a drospirenont tartalmazó OCP-k pedig kedvezóbbek a norgesztimát vagy a nomegesztrolttartalmú készítményekhez viszonyítva [39].

Enyhe fokú hirsutismus esetén dienogesztet vagy drospirenont tartalmazó készítmények egyaránt alkalmazhatók, de a közép- vagy súlyos fokú hirsutismus, illetve androgén alopecia esetén már a ciproteronacetát+EE tartalmú, illetve egyéb antiandrogén hatású készítmények alkalmazása javasolt [40].

\section{$\mathrm{Az}$ antiandrogének alkalmazása}

Ciproteron-acetát

A ciproteron-acetát (CPA) volt az első antiandrogén, amelyet 1964 óta használnak a klinikai gyakorlatban. Antiandrogén hatását elsősorban azzal fejti ki, hogy a sejtek citoplazmájában kiszorítja a dihidrotesztoszteront az androgén hatásért felelős receptorról, illetve kismértékben gátolja az 5-alfa-reduktáz aktivitását, így a tesztoszteron átalakulását aktív dihidrotesztoszteronná. Antigonadotrop hatása miatt csökkenti az ovarialis androgének mennyiségét. A CPA javasolt adagja hirsutismusnál $50-100 \mathrm{mg}$ a ciklus 10 . napján. Ugyanakkor a CPA alkalmazása hasonlóan eredményes lehet alacsonyabb dózisban $(5-10 \mathrm{mg})$ is $[41,42]$.

Mivel önmagában alkalmazva vérzészavar alakul ki, a ciproteron-acetát ösztrogénnel (ösztradiol vagy $\mathrm{CPA}+\mathrm{EE})$ kombinálva használható. A 2 mg CPA-t+EE-t tartalmazó készítmény acne kezelésére a drospirenont tartalmazó készítményekkel megegyező eredményessé- gú, de hirsutismusban eredményessége jobb [43, 44]. Alkalmazásánál lényeges tudni, hogy a CPA a VTE kialakulása szempontjából a magasabb kockázatot jelentő gesztagének közé tartozik.

A hiperandrogén bőrtünetek kezelésére, az előny-kockázat arányát mérlegelve, egyéb antiandrogén hatású készítmények (spironolacton, finasterid, flutamid) alkalmazása is előnyös lehet, bár ezek nem szerepelnek a hivatalos indikációban.

\section{Spironolacton, finasterid, flutamid}

$\mathrm{Az}$ aldoszteronantagonista spironolactonnak antiandrogén hatása is van. Napi 100-200 mg dózisban gátolja az 5-alfa-reduktáz aktivitását, és receptorszinten blokkolja a T/DHT hatását. Az OCP-vel szembeni elónye, hogy nem gátolja az ovulációt, nem okoz testtömeg-növekedést és kissé csökkenti az inzulinrezisztenciát. Monoterápiában polymenorrhoeát okozhat, amely a dózis csökkentésével (napi $100 \mathrm{mg}$-ról $50 \mathrm{mg}$-ra) vagy kiegészítő OCP-alkalmazással megszüntethető. Alkalmazása hirsutismus esetén jön szóba, acne kezelésére kevésbé eredményes $[45,46]$.

A prostata-hyperplasia kezelésére alkalmazható 5-alfareduktáz-gátló finasterid és a prostatacarcinoma terápiájára törzskönyvezett nem szteroid antiandrogén flutamid hatását is többen vizsgálták hirsutismus kezelésére.

$\mathrm{Az}$ antiandrogének hatásait értékelő vizsgálatok SR-je szerint az antiandrogének, a placebóhoz viszonyítva, az FG-score-t 3,9 ponttal csökkentik (95\% CI: 2,3-5,4). A metforminhoz viszonyítva a spironolacton $1,3(95 \% \mathrm{CI}$ : $0,03-2,6)$, a flutamid 5,0 ponttal $(95 \%$ CI $3,0-7,0)$ nagyobb mértékben csökkenti a hirsutismus mértékét. Napi $5 \mathrm{mg}$ finasterid eredményessége megegyezik az EE+CPA terápia eredményességével [47]. Dupla vak randomizált vizsgálat szerint a spironolacton hatásosságát a flutamiddal és a finasteriddel megegyezőnek találták [42]. A spironolacton vagy a finasterid OCP-vel történő kombinációja esetén az OR: 1,7 (95\% CI 0,1-3,3), a flutamid+MET kombinációjakor az OR: 4,6 [95\% CI: 1,3-7,9], amely kedvezőbb, mint az OCP- vagy a METmonoterápia. $\mathrm{Az}$ antiandrogének number needed to treat (NNT) értéke: $2-5$, de a nem megfelelően kivitelezett, alacsony esetszámú vizsgálatok miatt ennek tisztázására még további vizsgálatok szükségesek [42]. Az eddigi kutatások adatai szerint az antiandrogén terápia alkalmazása során kicsi a várható mellékhatások kialakulásának esélye [48].

Az előny-kockázatra vonatkozó bizonyítékok alapján az Endocrine Society a spironolactont a hirsutismus első, a finasteridet az alkalmazható készítmények második lépcsőjében javasolja [36, 40]. Az Amerikai Egyesült Államokból származó kutatási eredmények a CPA-ra vonatkozóan nincsenek, ugyanis a CPA-tartalmú készítmények forgalmazását az FDA nem engedélyezte.

Magyarországon a hiperandrogén terápia szempontjából mind a spironolacton, mind a finasterid az off label kategóriába tartozik. Alkalmazásuk, a megfelelő enge- 
3. táblázat | A hyperandrogenismus kezelésére alkalmazható készítmények összehasonlító eredményessége PCOS-ben

\begin{tabular}{|c|c|c|c|c|c|}
\hline Alkalmazott kezelés & $\begin{array}{l}\text { Viszonyított kezelés } \\
\text { (kontroll) }\end{array}$ & $\begin{array}{l}\text { Kezelés eredményessége } \\
\text { a kontrollhoz viszonyítva }\end{array}$ & Megjegyzés, értékelés & $\mathrm{E}$ & $\mathrm{R}$ \\
\hline $\begin{array}{l}\mathrm{EE}+\mathrm{CPA} \\
\text { (napi } 1 \text { tabletta) }\end{array}$ & $\mathrm{EE}+\mathrm{DRSP}$ & $\begin{array}{l}\text { Acne javulása: } \\
\text { EE+CPA: } 58,8 \% \\
\text { EE+DRSP: } 62,5 \%\end{array}$ & $\begin{array}{l}\text { Az acne kezelésére mindkét } \\
\text { készítmény hasonló eredményességgel } \\
\text { javasolható. }\end{array}$ & $1 b$ & 44 \\
\hline $\begin{array}{l}\mathrm{EE}+\mathrm{CPA} \\
\text { (napi } 1 \text { tabletta) }\end{array}$ & EE+DRSP & $\begin{array}{l}\text { Hirsutismus csökkenése (FG-score): } \\
\text { EE+CPA: }-35 \%[(-71)-10] \\
\text { EE+DRSP: }-18 \%[(-72)-30]\end{array}$ & $\begin{array}{l}\text { A EE+CPA szignifikánsan kedvezőbb } \\
\text { a hirsutismus kezelésére }(\mathrm{p}=0,035) \text {. } \\
\text { A két készítmény között nincs } \\
\text { különbség a metabolikus paraméterek } \\
\text { szempontjából. }\end{array}$ & $2 b$ & 45 \\
\hline $\begin{array}{l}\text { Dexamethason } \\
\text { (napi } 0,25-0,5 \mathrm{mg} \text { ) }\end{array}$ & $\mathrm{EE}+\mathrm{CPA}$ & $\begin{array}{l}\text { Hirsutismus csökkenése (FG-score): } \\
\text { Kortikoszteroid: } 31 \% \\
\text { EE+CPA: } 66 \%\end{array}$ & $\begin{array}{l}\text { CAH-ban alkalmazva a } \\
\text { kortikoszteroid nem csökkenti jobban } \\
\text { a hirsutismust az EE+CPA-hoz } \\
\text { viszonyítva. }\end{array}$ & 4 & 50 \\
\hline $\begin{array}{l}\text { Spironolacton* } \\
(100 \mathrm{mg} / \mathrm{nap})\end{array}$ & Placebo & $\begin{array}{l}\text { Hirsutismus csökkenése (FG-score): } \\
\text { WMD: } 7,20 \text { [95\% CI: }(-10,98)- \\
(-3,42)]\end{array}$ & $\begin{array}{l}\text { Hathavi kezelés alatt a spironolacton } \\
\text { kedvezőbb volt a placebónal. }\end{array}$ & la & 46 \\
\hline $\begin{array}{l}\text { Spironolacton* } \\
(100 \mathrm{mg} / \mathrm{nap})\end{array}$ & $\begin{array}{l}\text { CPA }(12,5 \mathrm{mg} / \text { nap ciklus } \\
\text { első } 10 \text { napján })\end{array}$ & $\begin{array}{l}\text { Hirsutismus javulása (FG-score): } \\
\text { WMD }-1,18 \text { [95\% CI: }(-2,1)-(-0,26)]\end{array}$ & $\begin{array}{l}12 \text { havi kezelés során szignifikánsan } \\
\text { eredményesebb a spironolacton. }\end{array}$ & la & 46 \\
\hline $\begin{array}{l}\text { Spironolacton* } \\
\text { (100 mg/ nap) }\end{array}$ & Finasterid* (5 mg/nap) & $\begin{array}{l}\text { Hirsutismus javulása (FG-score): } \\
\text { WMD }-2,34[95 \% \text { CI }(-3,23)-(-1,45)]\end{array}$ & $\begin{array}{l}12 \text { havi kezelés során szignifikáns } \\
\text { jobb a spironolacton. }\end{array}$ & la & 46 \\
\hline $\begin{array}{l}\text { Spironolacton* } \\
(50 \mathrm{mg} / \mathrm{nap})\end{array}$ & $\operatorname{MET}^{*}(1000 \mathrm{mg} / \mathrm{nap})$ & $\begin{array}{l}\text { Hirsutismus javulása (FG-score): } \\
-1,3 \text { (95\% CI: 0,03-2,6) }\end{array}$ & $\begin{array}{l}6 \text { havi kezelés során szignifikáns jobb } \\
\text { a spironolacton. }\end{array}$ & $2 b$ & 43 \\
\hline $\begin{array}{l}\text { Finasterid* } \\
(5 \mathrm{mg} / \mathrm{nap})\end{array}$ & $\begin{array}{l}\mathrm{EE}+\mathrm{CPA}(\mathrm{EE}: 20 \mu \mathrm{g} \mathrm{az} \\
\text { 5-25. napon, CPA: } 25 \mathrm{mg} \\
\text { az 5-14. napon) }\end{array}$ & $\begin{array}{l}\text { Hirsutismus javulása (FG-score): } \\
\text { Finasterid: } 48 \% \\
\text { EE+CPA: } 51 \%\end{array}$ & $\begin{array}{l}9 \text { hónapos kezelés során szignifikáns } \\
\text { különbséget nem igazoltak. }\end{array}$ & $2 \mathrm{~b}$ & 48 \\
\hline $\begin{array}{l}\text { Flutamid* } \\
(5 \mathrm{mg} / \mathrm{nap})\end{array}$ & $\mathrm{MET}^{*}(1000 \mathrm{mg} / \mathrm{nap})$ & $\begin{array}{l}\text { Hirsutismus javulása (FG-score): } \\
-5,0 \text { (95\% CI: 3,0-7,0) }\end{array}$ & $\begin{array}{l}\text { A flutamid jobban csökkenti a } \\
\text { hirsutismust, de májtoxikus hatása } \\
\text { miatt alkalmazása nem javasolt. }\end{array}$ & $2 b$ & 43 \\
\hline $\begin{array}{l}\mathrm{MET}^{*} \\
(1000 \pm 2000 \mathrm{mg})\end{array}$ & Placebo & $\begin{array}{l}\text { Hirsutismus javulása (FG-score): } \\
\text { WMD: }-1,5 \text { [95\% CI: }(-2,8)-(-0,2)]\end{array}$ & $\begin{array}{l}\text { Rotterdam/NIH szerinti diagnózis. } \\
\text { Klinikailag kismértékű különbség. }\end{array}$ & $2 b$ & 52 \\
\hline $\begin{array}{l}\mathrm{MET}^{*} \\
(1000-2000 \mathrm{mg})\end{array}$ & $\begin{array}{l}\text { OCP (CPA, DRSP, } \\
\text { NORG) }\end{array}$ & $\begin{array}{l}\text { Hirsutismus javulása (FG-score): } \\
\text { WMD: }-0,5 ;[95 \% \text { CI: }(-5,0)-(3,9)]\end{array}$ & $\begin{array}{l}\text { Rotterdam/NIH szerinti diagnózis. } \\
\text { A tüneteket a MET nem csökkenti } \\
\text { jobban, mint az OCP-k. }\end{array}$ & $2 b$ & 52 \\
\hline
\end{tabular}

dély birtokában, akkor lehet indokolt, ha az EE+CPA készítmények legalább egyéves kezelési eredményével a beteg nem elégedett. Az antiandrogéneket az OPC-hatású készítménnyel együtt szükséges alkalmazni, amellyel az antiandrogének nemkívánatos magzati mellékhatása megelőzheto".

\section{A kortikoszteroidok alkalmazása}

A PCOS-hez adrenális eredetû androgenismus (CAH) is társulhat [49]. Ezekben a kombinált esetekben a mellékvesekéreg-múködés visszaszorítására kiegészítő kortikoszteroidkezelés - éjszakára alacsony dózisban dexamethason $(0,25-0,5 \mathrm{mg})$ - alkalmazása is mérlegelhető, bár az EE+CPA-t tartalmazó készítményhez viszonyítva ez kevésbé eredményes a hirsutismus kezelésére (EE-CPA: 66\%, dexamethason: 31\%) [50]. A tartós dexamethasonkezelés CAH-val nem kombinált formáknál, ahol csak kismértékü a dehidroepiandroszteron(DHEA) vagy dehidroepiandroszteron-szulfát- (DHEAS) emelkedés - figyelembe véve azt is, hogy a DHEAS-nek kardioprotektív hatása is lehet - nem javasolt [51].

\section{A metformin alkalmazása}

A vizsgálatok alapján a jelenlegi bizonyítékok nem támasztják alá a metformin alkalmazását a hirsutismus kezelésére. Az eddig végzett, de nem megfelelő minőségű vizsgálatok miatt további, jól megtervezett vizsgálatokra van szükség ezen a területen is [52].

\section{Lokális eflornithin}

$\mathrm{Az}$ arcon kialakuló hirsutismus kiegészítő kezeléseként lokális eflornithin alkalmazása kísérelhető meg, amely csökkenti a szőrzet növekedési ütemét. Randomizált kontrollált vizsgálat során 24 hetes kezelést követően $58 \%$-ban észleltek javulást az arcon jelentkező fokozott szőrnövekedés esetén, míg a placebocsoportban a javulás csak 34\%-os volt [53] (3. táblázat).

\section{A meddóség kezelése}

\section{A kezelés első lépcsője}

Túlsúlyos vagy elhízott PCOS-betegeknél, még a gyógyszeres kezelés előtt, a testtömeg csökkentése javasolt. 
Anovulációval járó infertilitás gyógyszeres kezelésének továbbra is első vonalbeli szere a clomifen-citrát (CC), a második vonalbeli kezelés a gonadotropinok alkalmazása.

A CC kezdő adagja $25-50 \mathrm{mg} /$ nap a ciklus 2-5. napján. A dózis napi 150 mg-ig emelhető. A kezelés általában maximum hat cikluson keresztül folytatható. Amenynyiben ezt követően sem esik teherbe a beteg és IR igazolható, kiegészítő metforminkezelés kísérelhető meg $[54,55]$.

Főleg emelkedett DHEAS esetén, a ciklus 5-14. napja között, napi 2 mg kiegészítő dexamethasonkezelés javítja az ovulációindukció eredményességét [56].

A clomifen-citrát alkalmazásával a ciklusok 70-85\%ában lehet ovulációt igazolni, kumulatív terhességi ráta a hathavi kezelési időszakra vonatkozóan 50-60\% közötti [57].

\section{A kezelés második lépcsője}

A kezelés második lépcsőjét a gonadotropinok jelentik. Tekintettel arra, hogy a petefészek FSH-érzékenysége PCOS-ben megnő, a hiperstimuláció megelőzése érde- kében alacsony, napi 37,5-50 IU kezdő dózis javasolt. Az FSH-készítményt a ciklus 7-14. napja között javasolt alkalmazni. A kezelés hatását follikulometriával szükséges ellenórizni, amely kiegészíthető E2-mérésekkel. Ezek eredményei alapján adandó a humán choriogonadotropin- (hCG-) tartalmú készítmény az ovuláció kiváltására $[54,58]$. Az eddigi eredmények alapján a rekombináns FSH-készítmények (follitropin-alfa, follitropin-béta) alkalmazása előnyösebb az urofollitropint tartalmazó készítményeknél [59].

A kis dózisú, „step-up” FSH-protokoll három ciklus alatt eredményesebb a CC-kezelésnél. A terhességi arány $52,1 \%$ versus $41,2 \%(\mathrm{p}=0,021)$, kumulatív élveszületési arány $47,4 \%$ versus $36,9 \%, \mathrm{p}=0,031$ [60]. Hátránya, hogy a kiegészítő gonadotropinkezelés drágább, nagyobb az ovarialis hiperstimulációs szindróma (OHSS) kockázata, illetve a hCG-t vagy rekombináns LH-t tartalmazó készítmény alkalmazási időpontjának pontos meghatározása miatt nagyobb felügyeletet is igényel.

A mútéti eljárások ugyancsak a meddő PCOS-beteg kezelésének második lépcsőjébe sorolhatók. Ezek közül a laparoszkópos eljárással végzett petefészekdrilling

4. táblázat |A meddőség kezelésére alkalmazható készítmények összehasonlító eredményessége PCOS-ben

\begin{tabular}{|c|c|c|c|c|c|}
\hline Alkalmazott kezelés & $\begin{array}{l}\text { Viszonyított kezelés } \\
\text { (kontroll) }\end{array}$ & $\begin{array}{l}\text { Kezelés eredményessége } \\
\text { a kontrollhoz viszonyítva }\end{array}$ & Megjegyzés, értékelés & $\mathrm{E}$ & $\mathrm{R}$ \\
\hline CC (100 mg/nap) & Placebo & $\begin{array}{l}\text { Ovuláció aránya: } 70-85 \% \\
6 \text { havi kumulatí terhességi } \\
\text { arány: } 50-60 \%\end{array}$ & $\begin{array}{l}\text { Meddő PCOS-betegeknél CC az első } \\
\text { vonalbeli kezelés. }\end{array}$ & $2 b$ & 55 \\
\hline $\begin{array}{l}\mathrm{MET}^{*} \\
(1500 \mathrm{mg} / \mathrm{nap})\end{array}$ & CC (100 mg/nap) & $\begin{array}{l}\text { Ovuláció, nem elhizott: } \\
\text { OR: 0,87 (95\% CI: 0,60-1,26) } \\
\text { Ovuláció, elhizott: } \\
\text { OR: } 0,43 \text { (95\% CI: 0,36-0,51) } \\
\text { Terbesség, nem elhízott: } \\
\text { OR: } 1,94 \text { (95\% CI: } 1,19-3,16) \\
\text { Terhesség, elhizott: } \\
\text { OR: } 0,34 \text { (95\% CI: } 0,21-0,55)\end{array}$ & $\begin{array}{l}\text { A nem elhízott PCOS-betegeknél a MET } \\
\text { és a CC hasonló arányban eredményez } \\
\text { ovulációt. } \\
\text { Elhízottaknál a CC kedvezőbb. } \\
\text { A terhesség szempontjából a MET a nem } \\
\text { elhízott betegeknél kedvezőbb, elhízott } \\
\text { betegeknél kedvezőtlenebb } \\
\text { eredményességú a CC-hez viszonyítva. }\end{array}$ & $2 b$ & 66 \\
\hline $\begin{array}{l}\text { FSH } \\
\text { (kezdö adag: } 50 \text { IU/ } \\
\text { nap) }\end{array}$ & CC $(50-150 \mathrm{mg} / \mathrm{nap})$ & $\begin{array}{l}\text { Terhességi arány: }+10,9 \% \\
\text { Kumulatív élveszületési arány: } \\
+10,5 \%\end{array}$ & $\begin{array}{l}\text { A kis dózisú „step-up” FSH-protokoll } \\
\text { három ciklus alatt eredményesebb a } \\
\text { hagyományosan első vonalbelinek tartott } \\
\text { CC-kezelésnél, p }=0,031 \text {. }\end{array}$ & $1 b$ & 60 \\
\hline $\begin{array}{l}\text { Letrozol* } \\
(2,5-5,0 \mathrm{mg} / \mathrm{nap})\end{array}$ & CC (100 mg/nap) & $\begin{array}{l}\text { Ovuláció: } \\
\text { OR: 1,40 (95\% CI: 1,18-1,65) } \\
\text { Terbesség: } \\
\text { OR: } 1,63 \text { (95\% CI: } 1,31-2,03)\end{array}$ & $\begin{array}{l}\text { Tekintettel a nem megbízható, } \\
\text { heterogenitást mutató vizsgálatokra, az } \\
\text { aromatázgátlók rutinszerú alkalmazása } \\
\text { jelenleg még nem javasolható. }\end{array}$ & $2 b$ & 64,65 \\
\hline $\begin{array}{l}\mathrm{MET}^{*} \\
(1500-1700 \mathrm{mg} / \\
\text { nap) }\end{array}$ & Placebo & $\begin{array}{l}\text { Ovuláció: } \\
\text { OR: } 3,88 \text { (95\% CI: 2,25-6,69) } \\
\text { Terhesség: } \\
\text { OR: } 2,76 \text { (95\% CI: } 0,85-8,98)\end{array}$ & $\begin{array}{l}\text { NIH szerinti diagnózis. A MET } \\
\text { alkalmazásával a placebóhoz viszonyítva, } \\
\text { szignifikánsan }(\mathrm{p}<0,0001) \text { nőtt a peteérés } \\
\text { aránya (NNT: } 4,4) \text {, de a terhességek } \\
\text { száma nem nőtt. }\end{array}$ & $1 b$ & 65 \\
\hline $\begin{array}{l}\mathrm{MET}^{*}+\mathrm{CC} \\
(1500-1700 \mathrm{mg} / \\
\text { nap })+50-200 \mathrm{mg})\end{array}$ & CC (50-200 mg/nap) & $\begin{array}{l}\text { Ovuláció: } \\
\text { OR: } 4,41 \text { (95\% CI: 2,37-8,22) } \\
\text { Terbesség: } \\
\text { OR: } 4,4 \text { (95\% CI: } 1,96-9,85)\end{array}$ & $\begin{array}{l}\text { NIH szerinti diagnózis. A MET+CC } \\
\text { kombináció növeli }(\mathrm{p}<0,0001) \text { az ovuláció } \\
\text { arányát és a terhesség esélyét }(\mathrm{p}=0,0003) \\
\text { a CC-monoterápiához viszonyítva. }\end{array}$ & $1 b$ & 65 \\
\hline $\begin{array}{l}\mathrm{FSH}_{+} \mathrm{MET}^{*} \\
(50-75 \mathrm{IU}+1500- \\
1700 \mathrm{mg} / \mathrm{nap})\end{array}$ & FSH (50-75 IU/nap) & $\begin{array}{l}\text { Terbesség: } \\
\text { OR: } 2,25 \text { (95\% CI: 1,50-3,38) } \\
\text { Élveszületés: } \\
\text { OR: } 1,94 \text { (95\% CI: } 1,10-3,44)\end{array}$ & $\begin{array}{l}\text { ESHRE/ASRM, NIH szerinti diagnózis. } \\
\text { Az FSH mellé kiegészítő MET-terápia } \\
\text { szignifikánsan növeli a terhesség és az } \\
\text { élveszületés esélyét. }\end{array}$ & $2 b$ & 66 \\
\hline
\end{tabular}


5. táblázat | Mútéti vagy gyógyszeres kezelés és IVF során alkalmazott terápiák összehasonlító eredményessége PCOS-ben

\begin{tabular}{|c|c|c|c|c|c|}
\hline $\begin{array}{l}\text { Alkalmazott } \\
\text { kezelés }\end{array}$ & $\begin{array}{l}\text { Viszonyított kezelés } \\
\text { (kontroll) }\end{array}$ & $\begin{array}{l}\text { Kezelés eredményessége } \\
\text { a kontrollhoz viszonyítva }\end{array}$ & Megjegyzés, értékelés & $\mathrm{E}$ & $\mathrm{R}$ \\
\hline LOD & $\mathrm{CC}$ & Élveszületés: OR: 1,21 (95\% CI: 0,64-2,32) & $\begin{array}{l}\text { A LOD nem eredményesebb } \\
\text { a CC alkalmazásánál. }\end{array}$ & $2 b$ & 61 \\
\hline LOD & $\mathrm{CC}+\mathrm{MET}^{*}$ & Élveszületés: OR: 0,44 (95\% CI: 0,24-0,82) & $\begin{array}{l}\text { A CC+MET kombináció eredményesebb } \\
\text { a LOD-nál }(\mathrm{p}=0,01) \text {. }\end{array}$ & $2 b$ & 61 \\
\hline LOD & Gonadotropin & Élveszületés: OR: 0,97 (95\% CI: 0,59-1,59) & $\begin{array}{l}\text { A LOD nem eredményesebb } \\
\text { a gonadotropinok alkalmazásánál. }\end{array}$ & $2 \mathrm{~b}$ & 61 \\
\hline LOD & $\begin{array}{l}\text { Letrozol* } \\
(2,5-5,0 \mathrm{mg} / \mathrm{nap} \text { * }\end{array}$ & Élveszületés: OR: 0,84 (95\% CI: 0,54-1,31) & $\begin{array}{l}\text { A LOD nem eredményesebb } \\
\text { az aromatázgátlók alkalmazásánál. }\end{array}$ & $2 b$ & 61 \\
\hline $\begin{array}{l}\text { IVF+GnRH- } \\
\text { antagonisták }\end{array}$ & $\begin{array}{l}\text { IVF+GnRH- } \\
\text { agonisták }\end{array}$ & $\begin{array}{l}\text { OHSS kialakulása: OR: } 0,36 \\
(95 \% \mathrm{CI}: 0,25-0,52)\end{array}$ & $\begin{array}{l}\text { A klinikai terhességek számában vagy } \\
\text { a vetélések arányában nem igazolható } \\
\text { különbség. A GnRH-antagonisták csökkentik } \\
\text { az OHSS kialakulását. }\end{array}$ & la & 62 \\
\hline $\mathrm{IVF}+\mathrm{MET}^{*}$ & IVF & $\begin{array}{l}\text { Implantáció: OR: } 1,42 \text { (95\% CI: 1,24-2,75) } \\
\text { Kora terhességi vesztesség: OR: } 0,50 \\
\text { (95\% CI: 0,30-0,83) } \\
\text { OHHS: OR: } 0,27 \text { (95\% CI: } 0,16-0,46)\end{array}$ & Élveszületési arányt a MET nem javítja. & la & 68 \\
\hline
\end{tabular}

(LOD) a legelterjedtebben ajánlott módszer. A mütéti beavatkozás előtt azonban különösen mérlegelni szükséges a várható előnyöket és kockázatokat, illetve azt, hogy már minden egyéb gyógyszeres terápiás lehetőséget kihasználtunk-e. A műtéti megoldás mérlegelésének szükségességét egy 2007-ben végzett Cochrane-tanulmány eredménye támasztja alá. Ez alapján az élveszületések számában nem volt különbség a LOD és az egyéb kezelések között: CC (OR: 1,21 [95\% CI: 0,64-2,32]), gonadotropinok (OR: 0,97 [95\% CI: 0,59-1,59]), aromatázgátlók (OR: 0,84 [95\% CI: 0,54-1,31]). LOD elvégzése után szignifikánsan kevesebb volt az élveszületések száma is, a CC+MET kombinációval összehasonlítva (OR: 0,44 [95\% CI: $0,24-0,82], \mathrm{p}=0,01)$ [61].

\section{A kezelés harmadik lépcsője: IVF}

Meddő PCOS-betegek kezelésének harmadik lépcsője az in vitro fertilizáció (IVF) [54]. Metaanalízissel nem igazoltak különbséget „hosszú protokoll” szerint alkalmazott gonadotropin-releasing hormon ( $\mathrm{GnRH})$-agonisták (Ago) és GnRH-antagonisták (Ant) között sem az oocyták, sem a klinikai terhességek számában vagy a vetélések arányában.Ugyanakkor valószínű, hogy a GnRHantagonisták csökkentik az OHSS kialakulását (OR: 0,36 [95\% CI: 0,25-0,52]) a GnRH-agonistákhoz viszonyítva [62].

A szelektív aromatázinhibitorok alkalmazása meddőség esetén

Antiösztrogén hatásuk miatt szelektív aromatázinhibitorok alkalmazásának lehetősége is felmerül meddő PCOSbetegek kezelésénél. Ugyanakkor az eddigi vizsgálatok szerint nem egyértelmúek a letrozol és az anastrozol alkalmazásának előnyei a CC-rezisztens esetekben, bár letrozol alkalmazása javította a születési arányt a clomifencitráttal összehasonlítva (OR: 1,63 [95\% CI: 1,31-2,03]).
Tekintettel a nem megbízható módszerrel történt vizsgálatokra, ezeknek a készítményeknek rutinszerú alkalmazása jelenleg még nem javasolható $[63,64]$.

\section{A metformin alkalmazása meddőség esetén}

A metformin alkalmazásának eredményessége meddőség kezelésére sem egyértelmú még. A NIH szerinti kritériumok alapján diagnosztizált PCOS-tanulmányok szisztematikus értékelése szerint a MET a placebóhoz viszonyítva szignifikánsan $(\mathrm{p}<0,0001)$ növeli a peteérés arányát (OR: 3,88 [95\% CI: 2,25-6,69]), NNT: 4,4). Ugyanakkor a MET nem javította a klinikailag igazolt terhesség arányát (OR: 2,76 [95\% CI: 0,85-8,98]). A CC+MET kombináció szignifikánsan $(\mathrm{p}<0,0001)$ javítja az ovuláció arányát a CC-monoterápiához viszonyítva (OR: 4,41 [95\% CI: 2,37-8,22]), és szignifikánsan $(\mathrm{p}=0,0003)$ növeli a terhességek arányát a METmonoterápiához viszonyítva (OR: 4,4 [95\% CI: $1,96-9,85])[24]$.

A nem elhízott PCOS-betegeknél a MET és a CC hasonló arányban eredményez ovulációt (OR: 0,87 [95\% CI: 0,60-1,26]). Elhízottaknál a CC kedvezőbb (OR: 0,43 [95\% CI: 0,36-0,51]). Nem elhízott betegeknél a MET kedvezőbb a klinikailag igazolt terhesség szempontjából (OR: 1,94 [95\% CI: 1,19-3,16]), míg elhízott betegeknél kedvezőtlenebb eredményességű (OR: 0,34 [95\% CI: 0,21-0,55]). Az alacsony esetszám és heterogenitás miatt további vizsgálatok szükségesek [65].

Gonadotropinok mellé kiegészítő terápiaként alkalmazott MET szignifikánsan növeli a terhességek (OR: 2,25 [95\% CI: 1,50-3,38]) és az élveszületések esélyét (OR: 1,94 [95\% CI: 1,10-3,44]) [66].

A metformin növeli az implantáció valószínüségét is (OR: 1,42 [95\% CI: 1,24-2,75]), csökken a kora terhességi veszteség (OR: 0,50 [95\% CI: 0,30-0,83]) és az OHHS kialakulásának esélye (OR: 0,27 [95\% CI: 0,16- 
0,46]) de nem javítja sem a terhesség, sem az élveszületések arányát [66].

Mind a gonadotropinokkal való kombinációban, mind IVF során alkalmazott MET eredményességének egyértelmű tisztázására további vizsgálatok szülkségesek, tekintettel az eddigi kutatási adatok nem megfelelő validitására [67].

A terhesség alatt alkalmazott MET-terápia csökkenti a kora terhességi veszteséget (OR: 0,32 [95\% CI: 0,190,55]), a gesztációs diabetes (OR: 0,37 [95\% CI: 0,25$0,56]$ ), a praeeclampsia (OR: 0,53 [95\% CI: 0,30-0,95]) és a koraszülés (OR: 0,30 [95\% CI: 0,13-0,68]) kockázatát. A kezelés során lényegesebb anyai mellékhatásokat nem észleltek, és a major magzati fejlődési rendellenességek száma sem emelkedett (OR: 0,86 [95\% CI: 0,184,08]) $[68,69]$. A kutatási eredmények ellenére Magyarországon a metformin terhesség alatt sem alkalmazható (4. és 5. táblázat).

\section{A pszichés problémák kezelése}

Epidemiológiai tanulmányok alapján PCOS-ben négyszer gyakrabban fordul elő depresszió, mint a nem PCOS-es nők között. A lelki zavarok összefügghetnek a hirsutismussal, az elhízással és/vagy a meddőséggel, de az okok tisztázása további vizsgálatokat igényel [70]. Az okoktól függetlenül a lelki problémák pszichológiai gondozása javasolt, ami jelentősen javítja a PCOS-betegek életminőségét [71]. Szükség esetén pszichiátriai kezelés is indokolt lehet, de egy 2013-ban publikált Cochrane-tanulmány szerint jelenleg nincs még elég bizonyíték a PCOS-ben alkalmazott antidepresszánsok eredményességéról és biztonságáról [72].

A PCOS szövődményeinek prevenciója, kezelése, továbbá a bizonyítékon alapuló interdiszciplináris ellátás fontossága egy következő dolgozatban kerül ismertetésre.

Anyagi támogatás: A közlemény megírása anyagi támogatásban nem részesült.

Szerzői munkamegosztás: G. S.: Az irodalmi adatok keresése, az irodalom kritikus értékelése, a cikk összeállítása. Cs. O. K.: Az irodalmi adatok keresése, az irodalom kritikus értékelése. A cikk végleges változatát mindkét szerző elolvasta és jóváhagyta.

Érdekeltségek: A szerzőknek nincsenek érdekeltségeik.

\section{Irodalom}

[1] Sirmans, S. M., Pate, K. A.: Epidemiology, diagnosis, and management of polycystic ovary syndrome. Clin. Epidemiol., 2014, 6, $1-13$.

[2] Broekmans, F. J., Knauff, E. A., Valkenburg, O., et al.: PCOS according to the Rotterdam consensus criteria: change in preva- lence among WHO-II anovulation and association with metabolic factors. BJOG, 2006, 113(10), 1210-1217.

[3] Moran, L., Teede, H.: Metabolic features of the reproductive phenotypes of polycystic ovary syndrome. Hum. Reprod. Update, $2009,15(4), 477-488$.

[4] Kosova, G., Urbanek, M.: Genetics of the polycystic ovary syndrome. Mol. Cell. Endocrinol., 2013, 373(1-2), 29-38.

[5] Vitek, W., Hoeger, K. M.: Treatment of polycystic ovary syndrome in adolescence. Semin. Reprod. Med., 2014, 32(3), 214-221.

[6] Dunaif, A.: Diagnostic criteria used for polycystic ovary syndrome (PCOS). Evidence-based Methodology Workshop on Polycystic Ovary Syndrome. Bethesda, Maryland, December 3-5, 2012.

[7] Dunaif, A., Fauser, B. C.: Renaming PCOS - a two-state solution. J. Clin. Endocrinol. Metab., 2013, 98(11), 4325-4328.

[8] National Institutes of Health: Evidence-based Methodology Workshop on Polycystic Ovary Syndrome. Bethesda, Maryland, December 3-5, 2012. https://prevention.nih.gov/docs/programs/pcos/FinalReport.pdf

[9] Lim, S. S., Norman, R. J., Davies, M. J., et al.: The effect of obesity on polycystic ovary syndrome: a systematic review and metaanalysis. Obes. Rev., 2013, 14(2), 95-109.

[10] Juonala, M., Magnussen, C. G., Berenson, G. S., et al.: Childhood adiposity, adult adiposity, and cardiovascular risk factors. N. Engl. J. Med., 2011, 365(20), 1876-1885.

[11] Körner, A., Wiegand, S., Hungele, A., et al.: Longitudinal multicenter analysis on the course of glucose metabolism in obese children. Int. J. Obes. (Lond.), 2013, 37(7), 931-936.

[12] Jones, G. L., Hall, J. M., Balen, A. H., et al.: Health-related quality of life measurement in women with polycystic ovary syndrome: a systematic review. Hum. Reprod. Update, 2008, 14(1), $15-25$.

[13] Moran, L. J., Ko, H., Misso, M., et al.: Dietary composition in the treatment of polycystic ovary syndrome: a systematic review to inform evidence-based guidelines. J. Acad. Nutr. Diet., 2013, $113(4), 520-545$.

[14] Domecq, J. P., Prutsky, G., Mullan, R. J., et al.: Lifestyle modification programs in polycystic ovary syndrome: systematic review and meta-analysis. J. Clin. Endocrinol. Metab., 2013, 98(12), $4655-4663$.

[15] Miller,W. C., Koceja, D. M., Hamilton, E. J.: A meta-analysis of the past 25 years of weight loss research using diet, exercise or diet plus exercise intervention. Int. J. Obes. Relat. Metab. Disord., 1997, 21(10), 941-947.

[16] Motta, A. B.: The role of obesity in the development of polycystic ovary syndrome. Curr. Pharm. Des., 2012, 18(17), 2482-2491.

[17] Moran, L. J., Hutchison, S. K., Norman, R. J., et al.: Lifestyle changes in women with polycystic ovary syndrome. Cochrane Database Syst. Rev., 2011, 7, CD007506.

[18] Haqq, L., McFarlane, J., Dieberg, G., et al.: The effect of lifestyle intervention on body composition, glycaemic control and cardio-respiratory fitness in women with polycystic ovarian syndrome: a systematic review and meta-analysis. Int. J. Sport Nutr. Exerc. Metab., 2014 Mar 25. [Epub ahead of print]

[19] Haqq, L., McFarlane, J., Dieberg, G., et al.: Effect of lifestyle intervention on the reproductive endocrine profile in women with polycystic ovarian syndrome: a systematic review and meta-analysis. Endocr. Connect., 2014, 3(1), 36-46.

[20] Kumar, P., Arora, S.: Orlistat in polycystic ovarian syndrome reduces weight with improvement in lipid profile and pregnancy rates. J. Hum. Reprod. Sci., 2014, 7(4), 255-261.

[21] Woloshin, S., Schwartz, L. M.: The new weight-loss drugs, lorcaserin and phentermine-topiramate: slim pickings? JAMA Intern. Med., 2014, 174(4), 615-619.

[22] Yanovski, S. Z., Yanovski, J. A.: Naltrexone extended-release plus bupropion extended-release for treatment of obesity. JAMA, 2015, 313(12), 1213-1214. 
[23] Jensterle, M., Kravos, N. A., Pfeifer, M., et al.: A 12-week treatment with the long-acting glucagon-like peptide 1 receptor agonist liraglutide leads to significant weight loss in a subset of obese women with newly diagnosed polycystic ovary syndrome. Hormones (Athens), 2015, 14(1), 81-90.

[24] Lord, J. M., Flight, I. H., Norman, R. J.: Metformin in polycystic ovary syndrome: systematic review and meta-analysis. BMJ, 2003, 327(7421), 951-953.

[25] Nieuwenhuis-Ruifrok, A. E., Kuchenbecker, W. K., Hoek, A., et al. Insulin sensitizing drugs for weight loss in women of reproductive age who are overweight or obese: systematic review and meta-analysis. Hum. Reprod. Update, 2009, 15(1), 57-68.

[26] Glintborg, D., Altinok, M. L., Mumm, H., et al.: Body composition is improved during 12 months' treatment with metformin alone or combined with oral contraceptives compared with treatment with oral contraceptives in polycystic ovary syndrome. J. Clin. Endocrinol. Metab., 2014, 99(7), 2584-2591.

[27] Pasquali, R.: Metformin in women with PCOS, pros. Endocrine, $2015,48(2), 422-426$.

[28] Van $\operatorname{der} A a$, M. P., Elst, M. A., van Mil, E. G., et al.: Metformin: an efficacy, safety and pharmacokinetic study on the short-term and long-term use in obese children and adolescents - study protocol of a randomized controlled study. Trials, 2014, 15(1), 207.

[29] Burkman, R. T. Jr.: The role of oral contraceptives in the treatment of hyperandrogenic disorders. Am. J. Med., 1995, 98(1), 130S-136S.

[30] European Medicines Agency: Assessment report for combined hormonal contraceptives containing medicinal products. EMA/739865/2013. (http://www.ema.europa.eu/docs/en_ GB/document_library/Referrals_document/Combined_hormonal_contraceptives/Recommendation_provided_by_Pharmacovigilance_Risk_Assessment_Committee/WC500160272. pdf)

[31] Costello, M. F., Shrestha, B., Eden, J., et al.: Metformin versus oral contraceptive pill in polycystic ovary syndrome: a Cochrane review. Hum. Reprod., 2007, 22(5), 1200-1209.

[32] Halperin, I. J., Kumar, S. S., Stroup, D. F., et al.: The association between the combined oral contraceptive pill and insulin resistance, dysglycemia and dyslipidemia in women with polycystic ovary syndrome: a systematic review and meta-analysis of observational studies. Hum. Reprod., 2011, 26(1), 191-201.

[33] Harmanci, A., Cinar, N., Bayraktar, M., et al.: Oral contraceptive plus antiandrogen therapy and cardiometabolic risk in polycystic ovary syndrome. Clin. Endocrinol. (Oxf.), 2013, 78(1), $120-125$.

[34] Yildiz, B. O.: Approach to the patient: contraception in women with polycystic ovary syndrome. J. Clin. Endocrinol. Metab., $2015,100(3), 794-802$.

[35] Mendoza, N., Simoncini, T., Genazzani, A. D.: Hormonal contraceptive choice for women with PCOS: a systematic review of randomized trials and observational studies. Gynecol. Endocrinol., 2014, 30(12), 850-860.

[36] Legro, R. S., Arslanian, S. A., Ebrmann, D. A., et al.: Diagnosis and treatment of polycystic ovary syndrome: an Endocrine Society clinical practice guideline. J. Clin. Endocrinol. Metab., 2013, 98(12), 4565-4592.

[37] Ferriman, D., Gallwey, J.: Clinical assessment of body hair growth in women. J. Clin. Endocrinol. Metab., 1961, 21(11), 1440-1447.

[38] Elger, W., Beier, S., Pollow, K., et al.: Conception and pharmacodynamic profile of drospirenone. Steroids, 2003, 68(10-13), 891-905.

[39] Arowojolu, A. O., Gallo, M. F., Lopez, L. M., et al.: Combined ora contraceptive pills for treatment of acne. Cochrane Database Syst. Rev., 2012, 7, CD004425.

[40] Somani, N., Turvy, D.: Hirsutism: an evidence-based treatment update. Am. J. Clin. Dermatol., 2014, 15(3), 247-266.
[41] Van der Spuy, Z. M., le Roux, P. A.: Cyproterone acetate for hirsutism. Cochrane Database Syst. Rev., 2003, 4, CD001125.

[42] Swiglo, B. A., Cosma, M., Flynn, D. N., et al.: Antiandrogens for the treatment of hirsutism: a systematic review and metaanalyses of randomized controlled trials. J. Clin. Endocrinol. Metab., 2008, 93(4), 1153-1160.

[43] Van Vloten, W. A., van Haselen, C. W., van Zuuren, E. J., et al.: The effect of 2 combined oral contraceptives containing either drospirenone or cyproterone acetate on acne and seborrhea. $\mathrm{Cu}-$ tis, 2002, 69(4 Suppl.), 2-15.

[44] Kabraman, K., Sükür, Y. E., Atabekoğlu, C. S., et al.: Comparison of two oral contraceptive forms containing cyproterone acetate and drospirenone in the treatment of patients with polycystic ovary syndrome: a randomized clinical trial. Arch. Gynecol. Obstet., 2014, 290(2), 321-328.

[45] Brown, J., Farquhar, C., Lee, O., et al.: Spironolactone versus placebo or in combination with steroids for hirsutism and/or acne. Cochrane Database Syst. Rev., 2009, 2, CD000194.

[46] Badawy, A., Elnashar, A.: Treatment options for polycystic ovary syndrome. Int. J. Womens Health, 2011, 3, 25-35.

[47] Beigi, A., Sobbi, A., Zarrinkoub, F.: Finasteride versus cyproterone acetate-estrogen regimens in the treatment of hirsutism. Int. J. Gynecol. Obstet., 2004, 87(1), 29-33.

[48] Domecq, J. P., Prutsky, G., Mullan, R. J., et al.: Adverse effects of the common treatments for polycystic ovary syndrome: a systematic review and meta-analysis. J. Clin. Endocrinol. Metab., 2013, 98(12), 4646-4654.

[49] Azziz, R., Black, V., Hines, G. A., et al.: Adrenal androgen excess in the polycystic ovary syndrome: sensitivity and responsivity of the hypothalamic-pituitary-adrenal axis. J. Clin. Endocrinol. Metab., 1998, 83(7), 2317-2323.

[50] Frank-Raue, K., Junga, G., Raue, F., et al.: Therapie des Hirsutismus bei Frauen mit adrenalen Enzymdefekten der Steroidhormonbiosynthese: Vergleich von Dexamethason mit Cyproteronacetat. Klin. Wochensch., 1990, 68(12), 597-601.

[51] Goodarzi, M. O., Carmina, E., Azziz, R.: DHEA, DHEAS and PCOS. J. Steroid Biochem. Mol. Biol., 2015, 145, 213-225.

[52] Cosma, M., Swiglo, B. A., Flynn, D. N., et al.: Insulin sensitizers for the treatment of hirsutism: a systematic review and metaanalyses of randomized controlled trials. J. Clin. Endocrinol. Metab., 2008, 93(4), 1135-1142.

[53] Balfour, J. A., McClellan, K.: Topical eflornithine. Am. J. Clin. Dermatol., 2001, 2(3), 197-201.

[54] Thessaloniki ESHRE/ASRM-Sponsored PCOS Consensus Workshop Group: Consensus on infertility treatment related to polycystic ovary syndrome. Fertil. Steril., 2008, 89(3),505-522.

[55] Costello, M. F., Misso, M. L., Wong, J., et al.: The treatment of infertility in polycystic ovary syndrome: a brief update. Aust. N. Z. J. Obstet. Gynaecol., 2012, 52(4), 400-403.

[56] Parsanezhad, M. E., Alborzi, S., Motazedian, S., et al.: Use of dexamethasone and clomiphene citrate in the treatment of clomiphene citrate-resistant patients with polycystic ovary syndrome and normal dehydroepiandrosterone sulfate levels: a prospective, double-blind, placebo-controlled trial. Fertil. Steril., 2002, 78(5), 1001-1004.

[57] Balen, A. H.: Ovulation induction in the management of anovulatory polycystic ovary syndrome. Mol. Cell. Endocrinol., 2013, $373(1-2), 77-82$.

[58] Christin-Maitre, S., Hugues, J. N.: A comparative randomized multicentric study comparing the step-up versus step-down protocol in polycystic ovary syndrome. Hum. Reprod., 2003, 18(8), 1626-1631.

[59] Nugent, D., Vandekerckhove, P., Hughes, E., et al.: Gonadotrophin therapy for ovulation induction in subfertility associated with polycystic ovary syndrome. Cochrane Database Syst. Rev., 2000, 4, CD000410

[60] Homburg, R., Hendriks, M. L., König, T. E., et al.: Clomifene citrate or low-dose FSH for the first-line treatment of infertile 
women with anovulation associated with polycystic ovary syndrome: a prospective randomized multinational study. Hum. Reprod., 2012, 17(2), 468-473.

[61] Farquhar, C., Brown, J., Marjoribanks, J.: Laparoscopic drilling by diathermy or laser for ovulation induction in anovulatory polycystic ovary syndrome. Cochrane Database Syst. Rev., 2012, 6, CD001122.

[62] Xiao, J., Chen, S., Zhang, C., et al.: Effectiveness of GnRH antagonist in the treatment of patients with polycystic ovary syndrome undergoing IVF: a systematic review and meta analysis. Gynecol. Endocrinol., 2013, 29(3), 187-191.

[63] Misso, M. L., Wong, J. L., Teede, H. J., et al.: Aromatase inhibitors for PCOS: a systematic review and meta-analysis. J. Hum. Reprod. Update, 2012, 18(3), 301-312.

[64] Franik, S., Kremer J. A., Nelen, W. L., Farquhar, C.: Aromatase inhibitors for subfertile women with polycystic ovary syndrome. Cochrane Database Syst Rev., 2014, 2, CD010287.

[65] Tang, T., Lord, J. M., Norman R. J., et al.: Insulin-sensitising drugs (metformin, rosiglitazone, pioglitazone, D-chiro-inositol) for women with polycystic ovary syndrome, oligo amenorrhoea and subfertility. Cochrane Database Syst. Rev., 2012, 5, CD003053.

[66] Palomba, S., Falbo, A., La Sala, G. B.: Metformin and gonadotropins for ovulation induction in patients with polycystic ovary syndrome: a systematic review with meta-analysis of randomized controlled trials. Reprod. Biol. Endocrinol., 2014, 12, 3.

[67] Palomba, S., Falbo, A., La Sala, G. B.: Effects of metformin in women with polycystic ovary syndrome treated with gonadotro- phins for in vitro fertilisation and intracytoplasmic sperm injection cycles: a systematic review and meta-analysis of randomised controlled trials. BJOG, 2013, 120(3), 267-276.

[68] Zheng, J., Shan, P. F., Gu, W.: The efficacy of metformin in pregnant women with polycystic ovary syndrome: a meta-analysis of clinical trials. J. Endocrinol. Invest., 2013, 36(10), 797-802.

[69] Cassina, M., Donà, M., Di Gianantonio, E., et al.: First-trimester exposure to metformin and risk of birth defects: a systematic review and meta-analysis. Hum. Reprod. Update, 2014, 20(5), 656-669.

[70] Dokras, A., Clifton, S., Futterweit, W., et al: Increased prevalence of anxiety symptoms in women with polycystic ovary syndrome: systematic review and meta-analysis. Fertil. Steril., 2012, 97(1), 225-230.e2.

[71] Farrell, K., Antoni, M. H.: Insulin resistance, obesity, inflammation, and depression in polycystic ovary syndrome: biobehavioral mechanisms and interventions. Fertil. Steril., 2010, 94(5), $1565-1574$.

[72] Zhuang, J., Wang, X., Xu, L., et al.: Antidepressants for polycystic ovary syndrome. Cochrane Database Syst. Rev., 2013, 5, CD008575.

\section{Az Orvosi Hetilap 2015, 156, 1640. oldalán (40. szám) megjelent OH-Kvízre három helyes megfejtés érkezett.}

(Gődény Sándor dr., Debrecen, Kassai u. 26., 4028 e-mail: godeny.sandor@sph.unideb.hu)

A beküldők: Dr. Bíró László (Budapest), Dr. Janik Leonárd (Budapest) és Dr. Pallos Ágnes (Budapest)

A nyerteseknek szívböl gratulálunk.

A nyereményüket - egy, az Akadémiai Kiadó webáruházában

kedvezményes vásárlásra jogosító kupont - e-mailen küldjük el. 